\title{
Constructing National Identities in Newspapers
}

\author{
Dr. Mary Karuri ${ }^{1}$, Nabea Nkoru ${ }^{1}$ \\ ${ }^{I}$ Chuka University P.O Box 109-60400 Chuka. Kenya.
}

*Corresponding Author: Dr. Mary Karuri, Chuka University P.O Box 109-60400 Chuka. Kenya

\begin{abstract}
This article discusses the construction of national identities by newspaper writers in times of political conflict. In Kenya, the period 2008-2013, was characterized by political strife due to a forced coalition government between the two major political parties, Party of National Unity (PNU) and Orange Democratic Movement (ODM) led by Mwai Kibaki and Raila Odinga respectively. The coalition came after a disputed election that led to post-election violence. National identities are more explicitly expressed during moments of conflict than other times. The privileged position of media in accessing and diffusing the discourses of the powerful makes it possible for the media to attempt to influence the thinking of the general populace towards certain ideological ends especially in matters political. The two main newspapers in Kenya -Daily Nation and The Standard informed by their ideological convictions, created certain identities of the nation, reflecting their own interests. Through extensive use of metaphor, lexicon and structure, the newspapers construct negative and largely exaggerated images of the nation, at times portraying Kenya as a completely failed country. This paper explores this phenomenon using the Critical Discourse Analysis (CDA) framework which relates language use to social structure, emphasizing on the use of discourse in enactment of asymmetrical power relations.
\end{abstract}

Keywords: Ideological Stance, Identities, CDA, Asymmetrical Power Relations

\section{INTRODUCTION}

News reports as a media genre has received so much interest by mass communication researchers, linguists and discourse analysts because news is important in our daily lives since our social and political knowledge emanate from the news we hear and read every day. What the public refers to as 'news' from the media is misleading as Bell (1991) observes. He argues that if news was really actual reports of events as news makers would have us believe, then nobody would bother to read them because they would 'smack of dry, detached and depersonalized writing'. Instead, news is conceived and reported as 'stories', which means that it actually undergoes transformation and acquires 'a recognizable structure, direction and viewpoint in order to become 'palatable for general consumption' (Bell 1991:147). There is evidence that when news goes through 'editorial' processes during production, it is made to take a certain angle which the audience is expected to be persuaded to adopt.

The question whether or not an event will become news is important in considering the dynamics of media reports. Galtung and Ruge (1965) refer to 'news factors' as being the determinants of newsworthiness of an event. The factors are specific properties of an event and may include the conflict related to the message, the unexpectedness or novelty of the event, the possibility of dramatization and personalization and the status of an actor. Powerful social actors will have privileged access to the media. This in effect turns their formal power into discursive power leading to 'self- perpetuating cycle of political influence and media coverage'. Many newspapers have a recognizable editorial profile reflecting their political identity and it remains relatively consistent over time (Mc Nair, 1995). The profile is expressed in editorials which are considered the legitimate voice of media.

Factors that influence how news is packaged apart from the news itself need to be considered in analyzing mass media communication. The factors largely have to do with the economics and politics of the mass media; that is, the nature of the market and how the media relates to the state (Fairclough, 1995). Many scholars (Dijk 1991, 1993; Fowler 1991; Fairclough, 1995) have argued that the mainstream media is in the service of the powerful, the elite and the state and it contributes to 
reproduction of social relations of domination and exploitation. This fact is demonstrated by an American journalist's reflection on his coverage of US government briefings at the time when US invaded Iraq in 2003.

Well, I always personally found [US government briefings] valuable. I know many other people didn't because if you looked at them in terms of objective truth, they weren't very useful. But in terms how the US government wanted to see things, they were quite useful. And it's important to know what the government's narrative is. Because in any conflict there are competing narratives, and our job, from my point of view is to sort through them and provide a reality check on all of them (Columbia Journalism Review, 2006:28).

The text supports the view that journalist and news organizations have interests to serve as they go about writing and delivering news to people. Among the many 'narratives' that news reporters may have, they decide which one to perpetuate as the 'truth'. Chomsky (1994) argues that in its criticism of the state, the media's intention is to portray itself as the spokesman for free speech and general interest of community while in real sense, the media is itself a vehicle of hegemony. According to Fairclough and Chouliaraki (1999:24), hegemony involves 'naturalization of practices and their social relations as well as relations between practices, as matters of common sense'. For hegemony to thrive, ideology is important because it aids in achieving and maintaining relations of domination.

\subsection{Construction of National Identities}

Nations are imagined communities or mental constructs according to social theorists and analysts (Anderson, 1991; Miscevic, 2010).This means that national societies are not fixed and stable entities but constructed realities. Hence, when we think we are 'Kenyans', we are in essence constructing meanings that influence both our actions and our conceptions of ourselves and thus creating an entity called 'Kenya'.Billig (1995) argues that nationalism is a form of ideology that makes nations appear natural and further asserts that for nationalism to be able to occur, certain similar ideological habits of thought must be reproduced daily and this can happen through newspapers.Billig (ibid) observes that newspapers play an agentive role and a national frame of reference could be formed explicitly or implicitly through the content of newspaper. In other words, newspapers provide a discursive platform for constructing national identities.

Nations do not have fixed national identities because identities are not stable or consistent but 'dynamic, fragile, 'vulnerable' and often incoherent' (De Cillia, Reisigl, and Wodak, 1999). This means that national identities can be produced, reproduced, transformed and destructed. In their study on discursive construction of national identities focusing on Austria, DeCillia et al (1999) argue:

The idea of a specific national community becomes a reality in the realm of convictions and beliefs through reifying, figurative discourses continually launched by politicians, intellectuals and media people and disseminated through the systems of education, schooling, mass communication, militarization as well as through sports meetings (p. 6)

Hence, it is through such discursive sites that national identities can be articulated, or destructed. In this paper, I look at how newspapers, as a discursive site, conceive and construct national identities during times of political conflict.

Hardman (2008) explores ideology and identity creation in British newspaper editorials and argues that editorials, rather news reports are better sites in terms of encoding the ideological stance of a newspaper because they are openly persuasive. He observes that in editorials, the newspaper participates in public debate and readers also turn to editorials when they want interpretation of issues captured in news reports. This assertion is true but it also true that news reports are not objective reports of happenings and although not as explicit as editorials, they are usually written in such a way as to give them a definite viewpoint. Hence, though less explicit, headline texts and subsequent stories are also a suitable site for analysis of linguistic structures that point to more than just reporting on events, especially political ones.

Biased representation of identities are a common feature in newspaper reports asJuan Li (2009) demonstrates in her analysis of New York Times coverage of Kosovo war when the Chinese embassy in Yugoslavia was bombed by NATO in 1999. She explains how the representation of Chinese actors 
by New York Times displays the writer's and by extension, USA's ideological stance towards China after the bombing. In reporting on the incident, the New York Times represents the Chinese officials in the Chinese embassy involved in the aftermath of the bombing in an impersonal and general way as 'China' or 'Chinese embassy' or 'officials in Beijing'. Also, the newspaper reporter refers to them very few times. In contrast, the American officials are given a lot of attention and their names provided. The words of the Chinese officials are excluded, or given from the view points of the US officials or the news reporter. Such biased representation serves to undermine the salience and agency of the Chinese actors and downgrades their activities (Juan Li, 2009). The US officials on the other hand are shown as the ones who hold superior opinions on that matter. In addition, the generic reference makes the Chinese officials appear as a unit rather than individuals and this in effect demeans them.

School text books can also be used to advance national identities. Appleford (2008), for instance, demonstratess how an Australian text book implicitly reflects the ideological categories of the economic and social systems typical of Western capitalistic models. In describing Australian countryside, the author of the textbook conceives it in economic terms as having 'rolling tracts of pastoral land and magnificent beaches'. In contrast, the author describes Indonesia, a non-Western country, in terms of 'military regime' and 'demands for independence'. In written text, the writer creates an ideal audience and appropriates his or her views to the audience. In this case, the author's audience is Australian students and it is appropriate that they be trained to adapt to capitalist thinking right from a young age. In the this article, the crucial question is how the newspaper writers conceived the nation Kenya at a particularly volatile time politically.

\section{Methodology}

Newspapers written in the five-year period of the coalition government were sampled from University libraries. Theoretical sampling was the done to come up with the headline stories that would be considered "political" using a criterion proposed by Chilton and Schaffner (2011). The criterion proposes that political discourse should have aspects of legitimization, coercion and representation. In this study, coercion was taken to approximate closely to the persuasive discourse that newspapers use to make their point. Critical Discourse Analysis (CDA) was used both as a theory and a method to systematically illuminate and deconstruct the discourse texts in newspapers to show the underlying ideological biases.

\section{DISCUSSION}

This section categorizes and discusses the identities of the nation of Kenya that emerge from the stories by the two main newspapers written during the Coalition government.

\subsection{Kenya in Perpetual Warfare}

The disagreements between the coalition partners in government were often presented as warfare and chaos. The headlines texts combine lexicon, structure and imagery that all point to a permanent state of warfare between the coalition partners. Following are some of the headlines in both papers that used lexicon and imagery of war to portray the relationship between the coalition partners.

The listed headlines comprise expressions that have either direct or associative meaning to war such as 'knockout punch', 'fight', 'calling truce', 'marshaling troops', 'plotting offensive' among others. As observed earlier, The Standard newspaper had more dramatic and 'catchy' headlines than Daily Nation. The Standard had expressions such as 'explode' 'lock horns' and 'knock - out punch' while Daily Nation mainly uses the terms 'fight' 'war' and 'battle'. The Standard had also more headlines with war expressions. Headlines are the highest macro propositions (van Dijk, 1988), where news writers condense meaning in few words to summarize issues. The headlines carry the particular story's perspective. Thus, headlines themselves constitute autonomous texts that can be analyzed in their own light as discourses without the accompanying stories. In this sense then, whether or not the stories in tables 1 and 2 sustain the discourse of war explicitly does not change the underlying perception they create of the country as being in constant warfare. 
Table1. War Discourse in 'The Standard' Headlines.

\begin{tabular}{|l|l|}
\hline \multicolumn{1}{|c|}{ Date } & \\
\hline $16 / 10 / 2008$ & EXPLOSIVE \\
\hline $14 / 12 / 2008$ & The hidden wars \\
\hline $28 / 5 / 2008$ & New battle for Raila \\
\hline $8 / 3 / 2009$ & Sitting on a time bomb \\
\hline $13 / 4 / 2009$ & Parties fight to succeed Karua \\
\hline $27 / 2 / 2009$ & BOXED IN \\
\hline $9 / 4 / 2009$ & Fresh attack on Raila \\
\hline $21 / 4 / 2009$ & ODM secret weapons as house opens \\
\hline $30 / 4 / 2009$ & The next BIG battle \\
\hline $3 / 6 / 2009$ & ODM, PNU lock horns in Geneva \\
\hline $2 / 7 / 2007$ & LOCKING HORNS \\
\hline $7 / 9 / 2009$ & GREAT CONFRONTATION \\
\hline $6 / 10 / 2009$ & ODM and PNU rivalry explodes before Annan \\
\hline $18 / 2 / 2010$ & Battle goes to parliament \\
\hline $24 / 2 / 2009$ & SQUARING IT OUT \\
\hline $27 / 2 / 2010$ & Rivals plot the knockout punch \\
\hline $12 / 3 / 2010$ & PNU, ODM lock horns \\
\hline $29 / 3 / 2010$ & SHOWDOWN \\
\hline $7 / 10 / 2010$ & ODM, PNU go for each other's neck \\
\hline $27 / 1 / 2011$ & Cabinet tag of war \\
\hline $2 / 2 / 2011$ & CONFRONTATION \\
\hline $19 / 2 / 2011$ & Kibaki fights back \\
\hline $21 / 2 / 2011$ & Kibaki's allies turn up heat on Raila \\
\hline $22 / 2 / 2011$ & Marshalling troops \\
\hline
\end{tabular}

Table2. War Discourse in 'Daily Nation' Headlines.

\begin{tabular}{|l|l|}
\hline \multicolumn{1}{|c|}{ Date } & \\
\hline $7 / 4 / 2008$ & Battle over five key ministries \\
\hline $8 / 3 / 2009$ & ON THE WARPATH \\
\hline $23 / 4 / 2009$ & Deadlock in fight for house control \\
\hline $6 / 4 / 2009$ & Reforms at risk as parties step up war \\
\hline $3 / 9 / 2009$ & MPs defy Kibaki in battle over Ringera \\
\hline $14 / 2 / 2011$ & Principals at war \\
\hline $15 / 2 / 2010$ & Graft: Kibaki, Raila clash \\
\hline $3 / 1 / 2011$ & Raila urges calm as PNU plots offensive \\
\hline $18 / 2 / 2011$ & Kibaki: Why I'll fight to the end \\
\hline $21 / 2 / 2011$ & Pro Kibaki MPs take the battle to Marende \\
\hline $23 / 2 / 2011$ & Kibaki backs down as Raila calls truce \\
\hline $11 / 4 / 2011$ & Feuding parties plan rival meetings today \\
\hline $15 / 1 / 2012$ & Raila's secret weapon \\
\hline
\end{tabular}

The many lexical items associated with war point to over lexicalization which Fairclough (1989) defines as 'abundance of particular lexical items and their synonyms within a particular context of production and use'. Fairclough (ibid) argues that overlexicalization points to a preoccupation with a particular dimension of reality which is often a site for ideological struggle and contestation. During the coalition government, the conflict between the coalition partners lasted throughout the five years and this explains the overlexicalization of war metaphor. Specific features of discourses partly show the contexts of their production and they also serve as means of affecting the context (Fairclough, 1989). This means the war discourse may have been used by papers to reflect the situation of conflict as well as to communicate that the situation needed change.

The year 2010 saw political alignments taking shape in readiness for general elections which were to take place in 2012 before the date was altered to 2013 later. The strategizing by the various groups was captured as war in the headlines. Such a headline appeared on Feb 27, 2010, in The Standard: 'Rivals plot the knockout punch'. The headline is preceded by a kicker that runs: 


\section{Text 1:}

2012 BELLS: It's that season when a jittery elite retreat to their war rooms to plot against rivals, with PNU mulling new party in Naivasha and Raila consulting Matiba, ahead of murang'a visit.(Emphasis, mine)

The political strategizing is described in military language where the political elite 'retreat into their war rooms to plot against their rival' just as it happens in real battle. A particular discourse can attract many meanings so that there are no permanent fixations of meaning and 'articulations constantly shape and intervene in the structures of meaning in unpredictable ways' (Jorgensen \& Philips 2002). In text 1 , the politicians are preparing for elections. In the newspaper's interpretation, the 'preparation' acquires a new meaning and becomes strategizing as happens in war. This then ceases to be a simple mapping of one concept to another as in metaphorization but a more complex conception of Kenya. By choosing a military discourse in defining the circumstances of an election, The Standard creates an identity of a country in an internal state of vicious rivalry usually associated with enemy states in war.

The headline is accompanied by an image that reinforces the war discourse and emphasizes the divide between ODM and PNU parties with the members of PNU at one corner (Uhuru Kenyatta, Kalonzo Musyoka and George Saitoti) of the newspaper looking engrossed as if in a conspiracy against their 'rival', RailaOdinga who 'looks' on in a bemused demeanor as if in mockery of 'his enemies'. The body of the story extends the war discourse with the third paragraph explaining the 'conspiracy' suggested in the image.

\section{Text 2:}

The political heavy weights from the President's party retreated To Naivasha to strategize

for the killer punch as the public continued to view ODM as the most popular party in the country - a position that has obtained since before the botched 2007 elections.(emphasis, mine)

The use of the possessive 'president's party' distances the writer from the party as indication of his view of the politicians associated with the party. The assertion that the ODM party is the most popular party serves to counter the 'killer punch' being planned by the rival PNU and reinforce the identity of the country as a nation in war. Raila's strategizing for 2012 elections (after his political support in the rift valley region was seemingly waning) is described further thus:

\section{Text 3:}

Earlier in the week, reports indicate thatthe PM had retreated to the war room to strategize and sharpen his political claws following a jolt and realization that his support in his hitherto trongholds was gradually ebbing away following his fallout with cabinet ministers WilliamRuto and NajibBalala. (emphasis mine)

The text brings out a palpable image of viciousness ('sharpen his political claws') and depicts a picture of politicians who are ready to devour each other like animals. The story develops further and continues with the militarization of politics, describing Raila's former ally turned foe, Ruto, as having 'troops'. The PNU side of government has joined the said 'troops' in order to face their common foe, the PM. These lexicons serve to reinforce the overall metaphor of 'war'.

Laclau and Mouffe (1985) point to 'nodal points' or 'floating signifiers' to refer to situations that avail discursive evaluations by writers and other social commentators. In Kenya, the conflict in the coalition government provided the nodal points around which the news writers invested meaning in their own way. In forming particular views of the world, we exclude all the other possibilities in which the situation could have been interpreted. In essence, by investing in a particular meaning, we are involved in a process of 'reduction of possibilities'. This notion is important in explaining the newspapers' interpretation of politics as war. For instance, in the story, Rivals plan the knockout punch, the 'floating signifier' is the general elections and specifically, the strategizing that the politicians engaged in, in readiness for elections. That the strategizing should be interpreted in war terminology is the critical aspect here. In his choice of 'war' discourse, the writer excludes other possibilities such as 'planning', 'meeting to discuss possible alliances' and other interpretations. The choice reveals the writer's assessment of the situation but more significantly, constructs the nation's identity as one steeped in serious political rivalry akin to actual war. 
The Standard headline, Sitting on a time bomb was in apparent reference to a constitutional clause that stated that incase of incapacitation of a sitting president, the vice president would take over for 90 days till elections were held. This scenario would be problematic because the constitution had not been altered to accommodate the position of the prime minister. The writer envisages a situation where the president's seat would fall vacant but goes ahead to give a detailed analysis of the hypothesized scenario as if it were real. The headline represents the country as being in imminent danger and can 'blow' anytime. The image of a ticking bomb to capture an imagined situation is really an exaggeration and construes an identity of a country that is completely dysfunctional. The story itself is laden with misgivings on a myriad of issues as the following text shows.

Text 4:

The silence on the place of PM, who constitutionally appoint half the Cabine ministers who can't be fired by the president without his written consent, as well as the polarized nature of the coalition, could compound matters. Without a polls body, voters' register, new constitution to correct the anomalies of the 2007 chaotic elections, and a legal agreement on how to handle suspected perpetuators of the bloody post-election violence, Kenya stares at an uncertain and dreadful future

The whole paragraph is negativization of issues given in an enumerative style for emphasis. The mention of the 2007 election chaos is meant to remind the reader of possible consequences of failing to address the issues raised. Further, the reference to the country by its name in the final sentence serves to appeal the readers' consciousness about the collective entity they share (Kenya) to show that the issues raised are a grave common concern.

\subsection{Kenya as Chaotic and Hopeless}

The lingering political differences between the ruling coalition partners were portrayed as having a wider effect on the country and several stories depicted the country as incapable of delivering its mandate to the citizens. Consequently, headline texts and stories portrayed a state of chaos and hopelessness as captured by following headlines.

Table 3. Newspaper Headlines Representing Kenya as Chaotic and Hopeless

\begin{tabular}{|l|l|l|}
\hline \multicolumn{1}{|c|}{ Date } & \multicolumn{1}{|c|}{ Newspaper } & \multicolumn{1}{c|}{ Headline } \\
\hline $1 / 6 / 2008$ & The Standard & A nation in limbo \\
\hline $11 / 1 / 2009$ & The Standard & A new storm brews \\
\hline $22 / 3 / 2009$ & The Standard & Tower of Babel \\
\hline $5 / 4 / 2009$ & The Standard & Coalition in tatters \\
\hline $8 / 4 / 2009$ & The Standard & Mass action, threats, insults, resignations, what next? \\
\hline $10 / 4 / 2009$ & The Standard & Country on the cross \\
\hline $12 / 4 / 2009$ & The Standard & Reign of chaos \\
\hline $14 / 9 / 2009$ & The Standard & End of the road? \\
\hline $26 / 4 / 2009$ & The Standard & Who will blink first? \\
\hline $29 / 4 / 2009$ & The Standard & Order! Order! at last \\
\hline $4 / 2 / / 2011$ & The Standard & Calming the storm \\
\hline
\end{tabular}

The Standard of March 22, 2009 had the headline: Tower of Babel. This headline alludes to the biblical tower of babel whose construction was marred by confusion and chaos after the builders failed to understand one another's language. The parliament and by extension the country, is depicted as being in a state of confusion because the leaders cannot speak the same language. The lead part of the story is bolded for emphasis and spells the apparent confusion in parliament

Text 5:

House of confusion: There is disorder in Cabinet where 10 members want to be president and Kibaki, Raila are left singing different tunes in the Grand Coalition...

In April 2009, a group of politicians chosen from both ODM and PNU gathered at Naivasha in Rift Valley to iron out the differences in the Coalition. The meeting did not yield much. Against this background, The Standard on April 52009 ran the headline: Coalition in tatters The image "Tatters" represents a political situation that is beyond repair. The story itself further develops the metaphor of hopelessness, with other persuasive imagery meant to make the reader see the situation as dire as the following paragraph shows: 


\section{Text 6:}

The political antagonism and the blame game between party of national unity and orange democratic movement is now boiling over the melting pot. And Kenya could soon be in limbo. The fires of bitter rivalry between Kibaki and Raila momentarily quenched by power sharing have burst at the seams. (emphasis, mine)

The imagery used to describe the rivalry between the coalition partners such as 'boiling over the melting point', 'fires of bitter rivalry' and 'burst at the seams' is an extreme depiction of the Coalition Government as an entity that cannot hold anymore. The use of the imagery serves to emphasize the ideology that The Standard maintained throughout the five years of the Coalition Government that the government was not legitimate.

The metaphor of marriage is used several times to describe the relationship between the two sides of the coalition. The coalition is seen as a chaotic marriage of convenience and political expediency which would crumble any time. For instance, the Daily Nation of Feb 20, 2010 described the relationship thus:

\section{Text 7:}

The reform agenda comes last in the list of ODM demands to be discussed by the two leaders of a coalition government spoiling for a divorce but bound by the need for self-preservation.

Text 7 was written in the context of disagreement in the coalition concerning the powers of the PM in sacking ministers considered corrupt. But uncharacteristic of The Standard, the text shows some objectivity in the sense that it sees both sides of the coalition as selfish because the only thing that keeps them together is need for self-preservation and not concern for the country.

Metaphors are central in critical analysis of texts in the sense that they define the topic for the reader by conceptualizing issues in a certain way and persuade the readers to take a similar stance (Koller, 2004). It would seem that some metaphors are prolific and cut across media houses. The war metaphor in both The Standard and Daily Nation as seen in earlier discussions in this chapter is an example. The metaphor of a 'house' is also a common imagery in depiction of the European Union. The metaphor is used by media both in Europe and outside. However, the interpretation of the metaphor differs because of different attitudes towards the union. For instance, Chaban et al (2007) show the depiction of the 'house' in Australasian (Australia and New Zealand) News Media as an unstable, divided and overcrowded entity. In addition, the European Union is portrayed as a fragile piece of architecture with half-opened doors, walls and fences to lock out others. In contrast, the house image is interpreted positively by the media in Europe (Chaban et al 2007). Metaphors then can be seen as representations of attitudes.

On June 1 2008, Kenya was marking its $45^{\text {th }}$ Madaraka Day; that is, when the country achieved selfrule from its colonists. The Standard's headline presented an image of a country that could not hold itself much longer due to the wrangling that had plagued the Coalition Government since its formation three months earlier. The headline was: A nation in limbo. The story develops to draw analogy between human beings and the country. Just as humans experience midlife crisis at 45, so was Kenya doing as a country captured in the following text:

\section{Text 8:}

Kenya is 45 today since gaining self-governance and all around are literal signs of mid-life crisis. A nation we are but the tribulations, anxieties and trepidations of the last few months paint the picture of a nation at war with itself

The symbolism of mid-life crisis is supposed to portray a country which though reasonably old enough, is confused, insecure and doesn't seem to have any direction. Midlife crisis refers to a transitional age of 40-60 in adult development first identified by Freudian psychologist Carl Jung and developed by Levinson (1978). This is the age when people take stock of themselves and struggle with questions about their meaning and purpose in life and it may be characterized by confusion, doubt and boredom. In comparing Kenya to a person in midlife crisis, the writer is in essence saying that the country is in "limbo", a situation characterized by indecisiveness and stagnationas happens when a person is unable to cope with midlife crisis. The parallelism created in the above text is not 
just a simple comparison but a sophisticated parallelism of concepts, what Hardman (2008) calls 'hybrids'.

The story develops into a historical parallelism of the political situation in Kenya at independence and 2008. At independence, the political parties KANU and KADU had different positions on adoption of 'majimboism' (regional governments that were meant to shield small communities against possible domination by big tribes) with KANU not favouring it. The two parties then had reached a compromise with KADU agreeing to shelve the idea of majimboism until after independence, only for KANU to renege on the agreement and actually delete majimboism from the constitution. The comparison of the two periods of history was meant to prove that the Coalition Government would not last because, just as at independence, one side of the Coalition would betray the other. Although disagreement in the Grand Coalition Government was commonplace throughout the Coalition period, sometimes the newspapers 'kept the conflict going' even when there was no particular issue of disagreement. This was done through topicalizing issues that served to 'remind' the public of the conflicts in government. Such would seem to be the case when the story (A nation in limbo) was written because there was no immediate issue of conflict.

In The Standard headline, Raila warms up Nyanza for Kibaki, a cold relationship is implied between the two principals that necessitates the warming up of the Nyanza region for the president. In the opening paragraph, the story combines the discourse of the anticipated visit of the president to the birth place of the PM with the 2007/2008 post-election violence.

\section{Text 9:}

Prime Minister RailaOdinga will from today host President MwaiKibaki during his visit to Kisumu since post-election violence 19 months ago. Preparations were in top gear yesterday for the president's activity -packed visit that leaders say would help restore investor confidence in the province. Kibaki and Raila were bitter rivals in the 2007 General elections that ended up with major standoff over the presidential election results after Kibaki was declared the winner. The controversy spiraled into a political crisis when the country plunged into violence that left 1133 dead and about 600,000 displaced. Kisumu town, the headquarters of Nyanza Province which is the bedrock of Raila's political support was the scene of riots and killings that left the town scarred.

The Standard writer chooses to topicalize the post-election violence in the first, third and fourth paragraphs, giving details of the violence complete with figures as in paragraph four in text 9. The foregrounding of the post-election violence reorganizes the framework on which the discourse of the president's visit is interpreted and this can have social and political consequences. Such intrusion of discourses into other discourses to achieve certain ends has also been observed by Juan Li (2009).

During Easter Friday on April 10, 2009, The Standard had the headline, Country on the Cross in reference to the disagreements that had been raging between the Coalition partners over reforms. The text is reinforced by graphics where a cross is drawn cutting through a map of Kenya. The image signifies an apparent dire situation in the country because of political squabbling. The allusion to the cross is a rhetoric technique drawing parallelism between the situation in the country and the agony of Jesus on the cross. In the last part of the story, the writer quotes the president's Easter message of hope to the country but immediately juxtaposes it with an evaluative statement of hopelessness:

\section{Text 10:}

But for long suffering Kenyans dogged by many worries about tomorrow, the Easter weekend represents crucifixion in the actual sense of the word. (emphasis mine)

In this quote, the writer, while reporting the events of the Easter holiday evaluates the situation in the country and gives a verdict with finality. He paints a grim picture of the situation through the evaluative compound adjective 'long suffering' and the use of 'crucifixion'. In so doing, the writer is not just a reporter but an evaluator and interpreter of the political situation in the country. This is a common phenomenon in media discourse where the media portrays itself as the untainted moral authority that has the right to explain and interpret situations for the audience. Notable in the above quote also is the attempt to lump people together as 'long suffering Kenyans' to appear as if all Kenyans have a common stance to the prevailing political situation. This way, the writer is making a 
political indictment of the leadership and making it look like the view emanates from everybody. This narrative of a failed country continues in The Standard of $26^{\text {th }}$ April 2009 which captures the two principals engaged in a daring gaze at one another as the headline appropriately asks, Who will blink first? This was in the context of disagreement on leader of government business in parliament. The question and the image symbolically portray the perpetual state of conflict that Kenya was supposedly in for five years.

\section{CONCLUSiON}

In this article, we have seen the representation of national identities in newspaper discourse and the central role of metaphor in the creation of the identities. Through the use of certain metaphors and their associative lexicon, the papers construct negative identities for the country. The main metaphor that runs throughout the period of the coalition government is the war metaphor which depicts the country as being in a perpetual state of war. Other negative images depict the coalition government and the country as chaotic, disorderly and hopeless. The Standard uses more explicit language in depicting the country as being in bad shape politically and economically. The language and the images used for describing the country point to ideological interests of the particular media houses. Evidently, there is exaggeration of issues and indeed what may be seen as sensational journalism in the use of hybrid metaphors and graphics to persuade the reader that the country is at the brink of collapse.

\section{REFERENCES}

[1] Anderson, B. (1991). Imagined Communities: Reflections on the Origin and Spread of Nationalism. New York: Verso

[2] Appleford, G. (2008) Language and Nation. Roma: ARACNE editrice S. r. 1

[3] Bell, A. (1991). The Language ofNews Media. Oxford: Blackwell

[4] Billig, M. (1995).Banal Nationalism.London: Sage

[5] Chaban, N., Bain J., and Stats, K.(2007) 'Under Construction: Images of Enlarging EU in the Australasian News' Critical Approaches to Discourse Analysis across Disciplines 1 (2) 79-95

[6] Chilton, P. andSchaffner, C. (2011). 'Discourse and Politics'. In: van Dijk, T. (ed) Discourse Studies: A Multidisciplinary Introduction. London: Sage pp. 303-330

[7] Chomsky, N. (1994) World Orders, Old and New. New York: Columbia University Press.

[8] Chouliaraki, L. \&Fairclough, N. (1999).Rethinking Critical Discourse Analysis. Edinburgh: Edinburgh University Press

[9] De Cillia, R., Reisigl, M., \&Wodak, R. (1999). 'The Discursive Construction of National Identities' Discourse and Society 10: 149-173

[10] Fairclough, N. (1989). Language and Power. London: Longman.

[11] Fairclough, N. (1995). Critical Discourse Analysis: The Critical Study of Language. Harlow, UK: Longman

[12] Fowler, R. (1991). Language in the News: Discourse and Ideology in the Press. London: Routledge and Kegan Paul.

[13] Galtung J. and Ruge M.H. (1965) 'The Structure of Foreign News'.The Journal of Peace Research 2 (1) 64-91

[14] Hardman, D. (2008). Political Ideologies and Identity in British Newspaper Discourse Ph.D. thesis

[15] Jorgensen, M. and Phillips, L. (2002) Discourse Analysis as Theory and Method. London: SAGE Publications Ltd

[16] Juan Li (2009). 'Intertextuality and National Identity: Discourse of National Conflicts in Daily Newspapers in the United States and China'. Discourse and Society 20, 85-120

[17] Koller, V (2004) Metaphor and Gender in Business Media Discourse.Basingstoke: Palgrave Macmillan

[18] Laclau, E. and Mouffe, C(1985) Hegemony and Socialist Strategy.Towardsa Democratic Politics. London: Verso

[19] Levinson, D. (1978) The Seasons of a Man's Life. New York: Knopf

[20] Mc Nair, B. (1995)An Introduction to Political Communication $\left(5^{\text {th }}\right.$ ed.) NY: Routledge

[21] Miscevic, N., Nationalism, The Stanford Encyclopedia of Philosophy (Summer 2010 Edition), Edward N.Zalta(ed.),URLhttp://plato.stanford.edu/archives/sum2010 entries/nationalism/ 
[22] Reyes, A. (2011). 'Strategies of Legitimation in Political Discourse.From Words to Actions.' Discourse and Society 22, 781-807

[23] Van Dijk, T.A. (1988). News as Discourse.Hillsdale, NJ: Erlbaum.

[24] Van Dijk, T.A. (1991).Racism and the Press.London: Routledge.

[25] Van Dijk, T.A. (1993). Elite Discourse and Racism.Newsbury Park, CA: Sage

\section{AUTHOR'S BIOGRAPHY}

Dr. Mary Karuri, teaches linguistics at Chuka University in the department of humanities. She has a special interest in Discourse Analysis and especially Political Discourse.

Nabea Nkoru, He teaches communication and media at the department of social sciences in Chuka University. He is currently undertaking his $\mathrm{PhD}$ at the University

Citation: Dr. Mary Karuri, Nabea Nkoru, “Constructing National Identities in Newspapers " International Journal on Studies in English Language and Literature (IJSELL), vol 6, no. 1, 2018, pp. 1-10. doi:http://dx.doi.org/10.20431/2347-3134.0601001.

Copyright: (C) 2018 Authors. This is an open-access article distributed under the terms of the Creative Commons Attribution License, which permits unrestricted use, distribution, and reproduction in any medium, provided the original author and source are credited. 